\title{
SINTESIS PALMITOIL DAN LAUROIL ETANOLAMIDA MENGGUNAKAN PELARUT CAMPURAN : PENGARUH TEMPERATUR DAN WAKTU REAKSI
}

\author{
SYNTHESIS OF PALMITOYL AND LAUROYL ETHANOLAMIDES USING \\ MIXED SOLVENT: THE EFFECT OF TEMPERATURE AND REACTION TIME
}

\author{
Muhammad Ashari*, Nur Annisa, Zuhrina Masyithah \\ Departemen Teknik Kimia, Fakultas Teknik, Universitas Sumatera Utara \\ Jl. Almamater Kampus USU Medan 20155, Indonesia \\ *Email: muhammadashari180@gmail.com
}

\begin{abstract}
Abstrak
Surfaktan merupakan suatu molekul yang memiliki gugus hidrofilik dan gugus lipofilik sehingga dapat mempersatukan campuran yang terdiri dari air dan minyak. Alkanolamida merupakan salah satu jenis surfaktan nonionik yang banyak dimanfaatkan dalam berbagai keperluan. Pada penelitian ini, akan diamati pengaruh temperatur dan waktu reaksi terhadap sintesis surfaktan palmitoil etanolamida dari asam palmitat dan lauroil etanolamida dari asam laurat dengan katalis zirkonium (IV) klorida dalam pelarut campuran. Penelitian ini dilakukan dengan menggunakan reaksi amidasi pada temperatur $55^{\circ} \mathrm{C}, 65^{\circ} \mathrm{C}, 75^{\circ} \mathrm{C}, 85^{\circ} \mathrm{C}$ dan $95^{\circ} \mathrm{C}$, waktu reaksi selama $1 \mathrm{jam}, 2 \mathrm{jam}, 3 \mathrm{jam}, 4$ jam dan 5 jam, rasio mol substrat 1:10, jam pada rasio pelarut $2: 1(\mathrm{v} / \mathrm{b})$, konsentrasi katalis $5 \%$ (b/b), dan kecepatan pengadukan $250 \mathrm{rpm}$. Palmitoil dan lauroil etanolamida kemudian dianalisis dengan Spektrofotometri FT-IR. Berdasarkan penelitian ini didapatkan kondisi yang optimal pada suhu $55{ }^{\circ} \mathrm{C}$ untuk sintesis surfaktan palmitoil etanolamida dan temperatur $65{ }^{\circ} \mathrm{C}$ untuk sintesis surfaktan lauroil etanolamida, dan waktu reaksi 3 jam untuk masing-masing surfaktan.
\end{abstract}

Kata kunci: Alkanolamida, asam laurat, asam palmitat, monoetanolamina, surfaktan

\begin{abstract}
Surfactant is a molecule which has hydrophilic group and a lipophilic group which can unify a mixture consisting of water and oil. Alkanolamide is a type of widely used nonionic surfactant for various purposes. In this study, we observed the effect of temperature and reaction time on the synthesis of palmitoyl ethanolamide surfactant from palmitic acid and lauroyl ethanolamide from lauric acid with zirconium (IV) chloride as catalyst in mixed solvent. This research was conducted using amidation reaction at temperature variation of $55^{\circ} \mathrm{C}, 65^{\circ} \mathrm{C}, 75^{\circ} \mathrm{C}, 85^{\circ} \mathrm{C}$ and $95^{\circ} \mathrm{C}$, reaction time variation of 1 hour, 2 hours, 3 hours, 4 hours, and 5 hours, mole substrate ratio at 1:10, solvent ratio at 2: $1(\mathrm{v} / \mathrm{b})$, catalyst concentration $5 \%(\mathrm{w} / \mathrm{w})$, and stirring rate at $250 \mathrm{rpm}$. Then the product was analyzed by FT-IR spectrophotometry. Based on this research, the optimum condition to synthesis palmitoyl ethanolamide surfactant was obtained at $55^{\circ} \mathrm{C}$ and temperature $65^{\circ} \mathrm{C}$ to synthesis lauroyl ethanolamide surfactant at reaction time of 3 hours for both of them.
\end{abstract}

Keywords: Alkanolamide, lauric acid, palmitic acid, monoethanolamine, surfactant

\section{Pendahuluan}

Molekul surfaktan merupakan zat aktif permukaan dengan dua sifat yang berbeda. Bagian kepala bersifat polar dan bagian rantai alkil bersifat non-polar [5]. Molekul surfaktan pada bagian kepala disebut bagian hidrofilik dan bagian ekor disebut hidrofobik (Gambar 1). Bagian kepala dapat berupa kelompok anionik, kationik, zwitterion (amfoter) maupun kelompok nonionik sedangkan ekornya adalah rantai hidrokarbon [14].

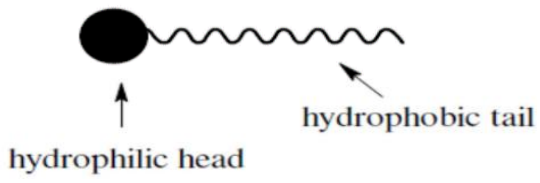

Gambar 1. Struktur Surfaktan
Surfaktan menyebabkan penurunan tegangan permukaan yang signifikan atau mengurangi tegangan permukaan antara dua cairan. Dengan menambah sejumlah kecil surfaktan, akan menyebabkan berkurangnya tegangan permukaan dan keadaan antarmuka akan berubah. Surfaktan dapat diaplikasikan sebagai agen pembasah, pengemulsi dan agen pembusa. Surfaktan memiliki sifat tegangan permukaan dan orientasi adsorpsi, sehingga membentuk dispersi, pembusaan, flokulasi, desinfeksi, dekontaminasi. Surfaktan juga banyak dimanfaatkan dalam industri pertambangan, tekstil, pencetakan, farmasi, lingkungan, makanan, kosmetik, pengolahan karet, industri pengolahan logam dan kertas [1]. 
Kelapa sawit (Elaeis guineensis, jacq) adalah salah satu tanaman perkebunan yang menjadi sumber devisa bagi Indonesia. Produksi kelapa sawit sebesar 11,08 juta ton tiap tahunnya dari luas perkebunan kelapa sawit sebesar 5 juta hektar. Produksi surfaktan dari turunan minyak kelapa sawit memiliki prospek yang sangat cerah di Indonesia. Hal ini karena surfaktan dari minyak kelapa sawit memberikan nilai tambah sampai 20 kali lipat lebih tinggi dibandingkan dengan harga $\mathrm{CPO}$ (Crude Palm Oil) saat ini [13].

Penelitian ini menggunakan pelarut campuran antara isopropil alkohol dengan heksana. Penggunaan pelarut campuran ini dipilih karena berdasarkan kelarutan bahan baku dan produk terhadap pelarut dimana produk amida yang dihasilkan dan monoetanolamina ternyata lebih larut dalam pelarut alkohol yang bersifat polar sedangkan asam lemak murni kurang larut dalam pelarut polar tetapi lebih larut dalam pelarut non polar seperti heksana. Dengan demikian, campuran alkohol dan heksana disarankan menjadi pelarut terbaik untuk reaksi penengahan karena campuran tersebut dapat melarutkan semua komponen yang diperlukan dan menghasilkan produk paling banyak [16].

Pada penelitian ini, akan disintesis surfaktan alkanoamida yaitu palmitoil etanolamida dan lauroil etanolamida dengan reaksi amidasi antara asam palmitat dan asam laurat dari turunan minyak sawit dengan monoetanolamina. Katalis yang digunakan adalah katalis logam zirkonium (IV) klorida karena keberadaannya yang cukup melimpah dan kemampuan mereka yang dpat bekerja dengan baik dalam semua pelarut dan mudah untuk direcycle.

\section{Teori}

Surfaktan memiliki kegunaan yang sangat bervariasi, mulai dari bahan deterjen, farmasi, kosmetik, tekstil, makanan, plastik dan lainnya. Gugus hidrofilik pada surfaktan bersifat polar dan gugus lipofiliknya bersifat non polar.

Berdasarkan gugus hidrofiliknya, surfaktan digolongkan menjadi 4 yaitu :

1. Surfaktan anionik

2. Surfaktan kationik

3. Surfaktan nonionik

4. Surfaktan amfoter [8]

\section{Asam Palmitat}

Asam palmitat merupakan komponen utama minyak dari pohon kelapa sawit (kelapa sawit dan inti kelapa sawit) yang merupakan asam lemak pertama yang dihasilkan pada proses lipogenesis (sintesis asam lemak) berupa asam karboksilat dengan ekor panjang dan tidak bercabang alifatik jenuh. Minyak kelapa sawit mengandung sekitar $50 \%$ asam palmitat. Penggunaan asam palmitat yang paling terkenal adalah sebagai komponen penting dalam pembuatan sabun. Asam palmitat merupakan sumber kalori penting, namun memiliki daya antioksidasi yang cukup rendah [7].

\section{Asam Laurat}

Asam laurat atau asam dodekanoat adalah asam lemak jenuh berantai sedang yang tersusun dari 12 atom C. Sumber utama asam lemak ini adalah minyak kelapa, yang dapat mengandung 40$60 \%$ asam laurat, serta minyak inti sawit (palm kernel oil) yaitu 40-50\% [17]. Asam laurat banyak digunakan dalam industri kosmetik yaitu sebagai pengental, pelembut, dan pelembab. Selain itu, karena sifat antimikrobialnya yang baik, asam laurat juga digunakan dalam industri obat-obatan [4].

\section{Surfaktan Alkanolamida}

Asam lemak etanolamida adalah salah satu kelas penting dalam kelompok surfaktan nonionik yang banyak diaplikasikan sebagai pelumas, surfaktan, deterjen, dan kosmetik [11]. Sifat fisikokimia tergantung dengan panjang rantai hidrokarbon dan kelompok fungsional pada rantai. Asam lemak etanolamida secara struktural termasuk dalam alkanolamida asam lemak dan keluarga lipida yang ditemukan secara alami di jaringan tumbuhan dan hewan [10]. Palmitoil etanolamida telah dicatat dapat digunakan untuk mengurangi reaksi alergi, menghambat degranulasi sel mast [12], menunjukkan aktivitas antiinflamasi dan mengurangi sensasi rasa sakit [6], dan dapat memberikan efek neuroprotektif pada tikus [2].

Senyawa-senyawa alkilamida digunakan sebagai obat maupun pencegah penyakit flu dan infeksi saluran pernapasan dalam bidang farmasi dan kedokteran [3].

\section{Bahan dan Metode \\ Alat}

Alat yang digunakan dalam penelitian ini antara lain labu leher tiga, refluks kondensor, termometer, erlenmeyer, corong pisah, gelas ukur, gelas kimia, neraca analitik, pipet tetes, hot plate, magnetic stirrer dan Tensiometer du Nouy.

\section{Bahan}

Bahan yang digunakan dalam penelitian ini adalah asam palmitat, asam laurat, monoetanolamina (MEA), zirkonium (IV) klorida $\left(\mathrm{ZrCl}_{4}\right)$ dari E Merck. Pelarut: n-heksana dan isopropil alkohol dari E Merck. Bahan analisis : $\mathrm{KOH}$, phenolpthalein, aseton, dan $\mathrm{HCl}$ semuanya dari E Merck.

\section{Prosedur Reaksi Amidasi}

Asam palmitat/asam laurat sebanyak $5 \mathrm{mg}$ dimasukkan ke dalam labu leher tiga. Ditambahkan pelarut heksana:isopropil alkohol (1:1) dengan rasio pelarut : substrat (asam palmitat/laurat + monoetanolamina) 2:1 (b/v). Ditambahkan monoetanolamina (MEA) dengan variasi rasio mol 
asam palmitat/laurat : monoetanolamina 1:10 kemudian di masukkan katalis zirkonium (IV) klorida dengan kosentrasi $1 \%$ terhadap berat asam palmitat/laurat (\% b/b).

Dipanaskan dengan labu leher tiga dengan pemanas hot plate pada variasi suhu operasi $55^{\circ} \mathrm{C}$, $65{ }^{\circ} \mathrm{C}, 75^{\circ} \mathrm{C}, 85^{\circ} \mathrm{C}$ dan $95^{\circ} \mathrm{C}$. dan diaduk dengan kecepatan putar $250 \mathrm{rpm}$. Kemudian direaksikan dengan variasi waktu operasi 1 jam, 2 jam, 3 jam, 4 jam dan 5 jam. Selanjutnya dihitung persen konversi untuk setiap variabel.

\section{Hasil dan Pembahasan}

Pengaruh Temperatur Reaksi Terhadap \% Konversi Asam Palmitat dan Asam Laurat

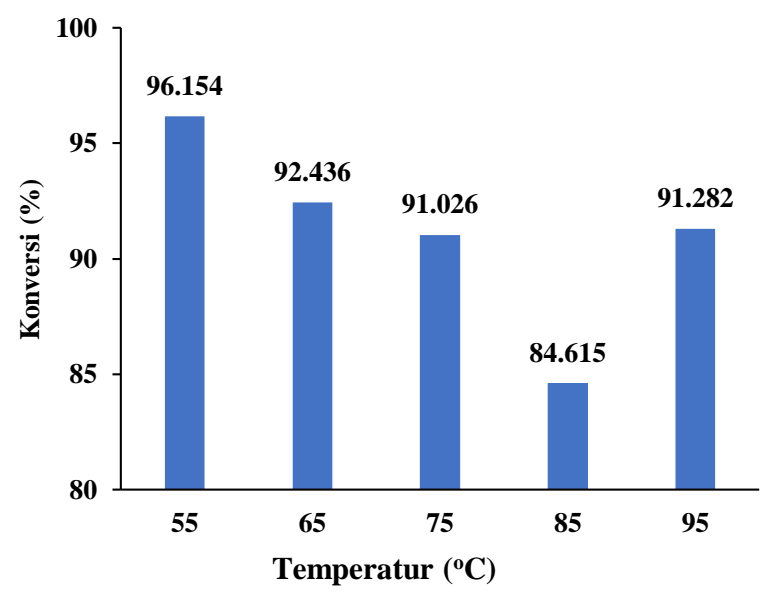

Gambar 2. Pengaruh Temperatur Reaksi Terhadap \% Konversi Asam Pamitat pada Waktu 3 jam

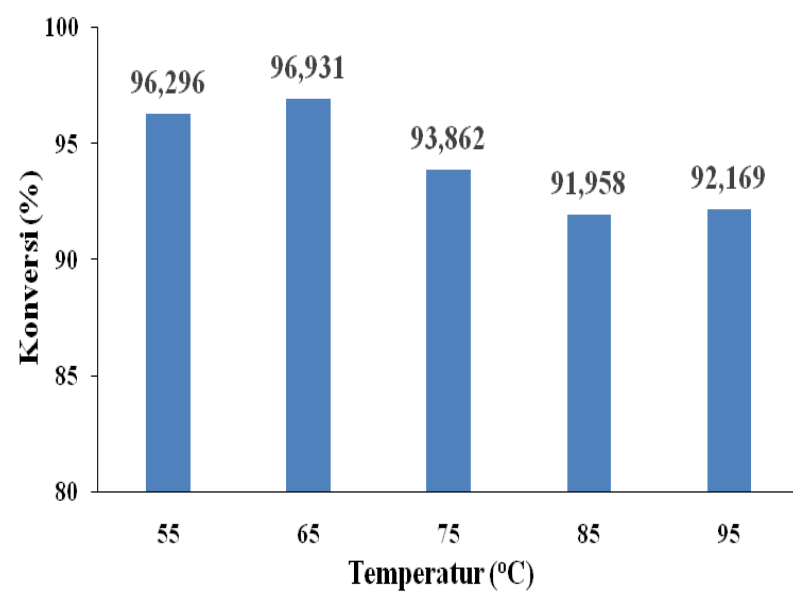

Gambar 3. Pengaruh Temperatur Reaksi Terhadap \% Konversi Asam Laurat pada Waktu 3 jam

Pengamatan sintesis palmitoil etanolamida pada Gambar 2 menunjukkan bahwa temperatur reaksi $55{ }^{\circ} \mathrm{C}$ memberikan konversi terbaik yaitu mencapai $96,154 \%$, dan mengalami penurunan pada temperatur $65{ }^{\circ} \mathrm{C}, 75{ }^{\circ} \mathrm{C}$ dan $85{ }^{\circ} \mathrm{C}$. Namun, mengalami peningkatan kembali pada temperatur 95 ${ }^{\circ} \mathrm{C}$. Persen konversi terendah pada $85{ }^{\circ} \mathrm{C}$ sebesar $84,615 \%$.

Sedangkan untuk sintesis lauroil etanolamida seperti yang ditunjukkan pada Gambar 3 diperoleh konversi terbaik yaitu pada temperatur $65^{\circ} \mathrm{C}$ dengan besar konversi 96,931\%.

Hasil ini terkait dengan reaksi samping yang dihasilkan dari reaksi seperti transesterifikasi antara reaktan dengan etanolamida dan asam lemak dan/atau dehidrasi etanolamida di bawah suhu tinggi [17]. Sehingga reaksi optimum suhu dipilih $55^{\circ} \mathrm{C}$ untuk palmitoil etanolamida dan $65^{\circ} \mathrm{C}$ untuk lauroil etanolamida.

\section{Pengaruh Waktu Reaksi Terhadap \% Konversi Asam Palmitat dan Asam Laur}

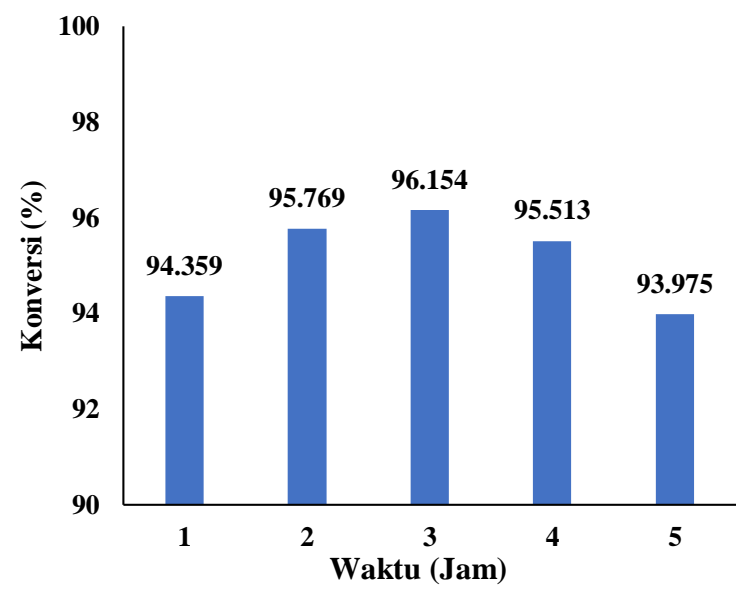

Gambar 4. Pengaruh Waktu Reaksi Terhadap \% Konversi Asam palmitat pada Temperatur Reaksi $55^{\circ} \mathrm{C}$

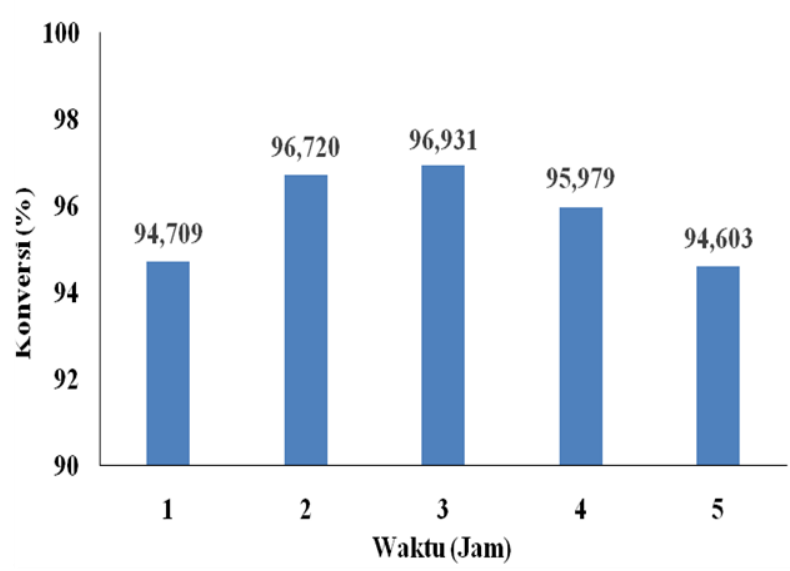

Gambar 5. Pengaruh Waktu Reaksi Terhadap \% Konversi Asam Laurat pada Temperatur Reaksi $65^{\circ} \mathrm{C}$

Hasil pengamatan sintesis surfaktan ditunjukkan pada Gambar 4 dan Gambar 5. Pada Gambar 4 dan Gambar 5 diperoleh persen konversi terbesar yaitu pada waktu reaksi 3 jam untuk sintesis palmitoil etanolamida dan lauroil etanolamida 
dengan besar persen konversi masing-masing $96,154 \%$ dan $96,931 \%$. Persen konversi mengalami peningkatan dari waktu reaksi 1 jam menuju 3 jam. Namun, mengalami penurunan ketika waktu reaksi 4 jam dan 5 jam.

Hal ini disebabkan karena terjadinya reaksi samping seperti saponifikasi [9]. Sedangkan berdasarkan penelitian yang dilakukan oleh Wang, dkk. (2016), peningkatan waktu reaksi tidak memberikan hasil yang signifikan terhadap perolehan amida [16]. Dari keterangan di atas dapat disimpulkan diperoleh waktu reaksi optimum selama 3 jam untuk sintesis palmitoil etanolamida dan lauroil etanolamida.

\section{Hasil Analisa Spektrum FT-IR}

Reaksi asam lemak dengan monoetanolamina (MEA) dengan katalis zirkonium IV klorida $\left(\mathrm{ZrCl}_{4}\right)$ pada konsentrasi $0,25(\mathrm{~b} / \mathrm{b})$ dapat membentuk senyawa amida. Senyawa amida yang terbentuk dapat berfungsi sebagai surfaktan. Adapun hasil spektrum surfaktan alkanoamida yang diperoleh ditunjukkan oleh Gambar 6.

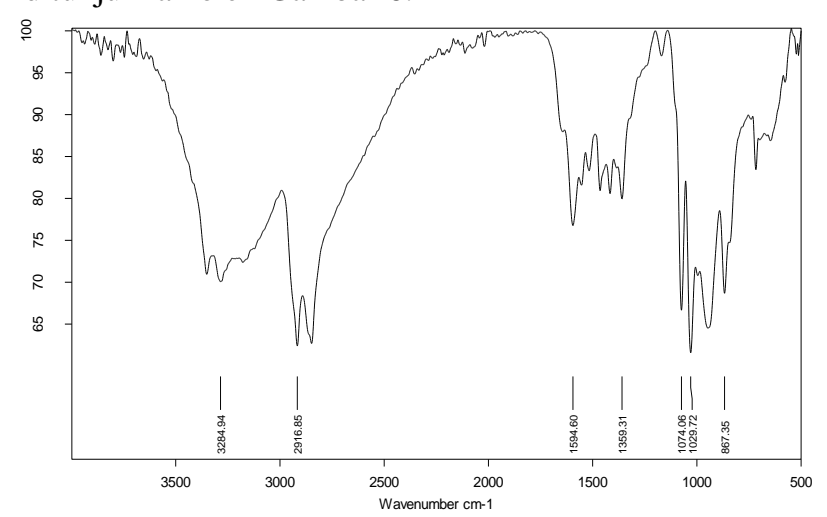

Gambar 6 Analisa FT-IR

Menurut Silverstein dan Webster, vibrasi untuk ikatan C-N untuk amina berada pada angka gelombang 1250-1020 $\mathrm{cm}^{-1}$. Dari hasil uji spektrum FTIR sampel, menunjukkan puncak resapan pada daerah bilangan gelombang 867,35 $\mathrm{cm}^{-1}$ menunjukkan adanya gugus N-H pada daerah bilangan gelombang ini yang menunjukkan sampel mengandung gugus amida. Sedangkan resapan pada bilangan gelombang $3284,94 \mathrm{~cm}^{-1}$ menunjukkan adanya gugus $\mathrm{OH}$. Gugus $\mathrm{OH}$ terdapat pada senyawa monoetanolamina.

Gambar 6 menunjukkan puncak resapan pada bilangan gelombang 2916,86 $\mathrm{cm}^{-1}$ menunjukkan adanya gugus $\mathrm{C}-\mathrm{H}$ [15].

\section{Kesimpulan}

Kesimpulan dari penelitian ini adalah :

1. Kondisi reaksi terbaik pada penelitian ini untuk sintesis surfaktan palmitoil etanolamida yaitu waktu reaksi 3 jam dan temperatur reaksi 55 ${ }^{\circ} \mathrm{C}$.
2. Kondisi reaksi terbaik pada penelitian in untuk sintesis surfaktan lauroil etanolamida yaitu waktu reaksi 3 jam dan temperatur reaksi 65 ${ }^{\circ} \mathrm{C}$.

3. Pengamatan sintesis palmitoil etanolamida ini menunjukkan bahwa pada temperatur reaksi 55 ${ }^{\circ} \mathrm{C}$ dan waktu reaksi 3 jam memberikan konversi terbaik yaitu mencapai 96,154\%

4. Pengamatan sintesis lauroil etanolamida memberikan konversi terbaik sebesar $96,931 \%$ pada temperatur reaksi $65{ }^{\circ} \mathrm{C}$ dan waktu reaksi selama 3 jam.

5. Persen konversi asam palmitat maupun asam laurat mengalami peningkatan dari waktu reaksi 1 jam menuju 3 jam. Namun, mengalami penurunan ketika waktu reaksi 4 jam dan 5 jam.

\section{Daftar Pustaka}

[1] C. L. Yuan, Z. Z. Xu, M. X. Fan, H. Y. Liu, H. Xie and T. Zhu, Study on characteristics and harm of surfactants, J. Chem. Pharm. Res. 2014, 6(7): 2233-2237.

[2] D. M. Lambert, S. Vandevoorde, G. Diependaele, S. J. Govaerts, A. R. Robert, Anticonvulsant activity of $\mathrm{N}$ palmitoylethanolamide, a putative endocannabinoid, in mice, Epilepsia , 2001, 42:321-327.

[3] E. R. Gunawan, D. Suhendra, D. Asnawati, I M. Sudarma, I. Zulpiani. Sintesis Asam-Asam Lemak Amida Dari Ekstrak Minyak Inti Buah Nyamplung (Calophyllum Inophyllum) Melalui Reaksi Enzimatik, Prosiding Seminar Nasional Kimia, 2014, ISBN : 978-602095100-3.

[4] F. O. Nitbani, Jumina, D. Siswanta, E. N. Solikhah, Isolation and Antibacterial Activity Test of Lauric Acid from Crude Coconut Oil (Cocos nucifera L.), Procedia Chemistry, Universitas Gadjah Mada, Yogyakarta, 2015, Volume 18, Halaman 132-140.

[5] G. A. Cookey dan O. U. Daniel. Micellization of a Cationic Surfactant in Mixed Aqueous and Non-aqueous Solvent System, J. App. Sci. Environ, Manage, 2015, JASEM ISSN 1119 8362.

[6] G. Re, R. Barbero, A. Miolo, V. D. Marzo, Palmitoylethanolamide, endocannabinoids and related cannabimimetic compounds in protection against tissue inflmmation and pain: potential use in companion animals, Vet $\mathrm{J}$, 2007, 173:21-30.

[7] Irwansyah, Transformasi Kitosan Dan Asam Palmitat Menjadi N-Palmitil Kitosan, Tesis, Fakultas Matematika Dan Ilmu Pengetahuan Alam, Universitas Sumatera Utara, Medan, 2011. 
[8] J. R. Oppusungu, V. R. Siregr, Z. Masyithah, Pengaruh Jenis Pelarut Dan Temperatur Reaksi pada Sintesis Surfaktan Dari Asam Oleat Dan N-Metil Glukamina Dengan Katalis Kimia, Jurnal Teknik Kimia USU, 2015, Vol. 4, No. 1.

[9] J. Zhang, D. Cai, S. Wang, Y. Tang, Z. Zhang, Y. Liu, X. Gao, Efficient Method For The Synthesis of Fatty Acid Amide from Soybean Oil Methyl Ester Catalysed by Modified $\mathrm{CaO}$, The Canadian Journal of Chemical Engineering, 2014, Volume 92, DOI $10.1002 /$ cjce. 21948 .

[10] K. D. Chapman. Emerging physiological roles for Nacylphosphatidyl ethanolamine metabolism in plants: signal transduction and membrane protection, Chem. Phys. Lipids, 2000, 108, $221-229$.

[11] K. J. Liu, A. Nag, dan J. F. Shaw. Lipasecatalyzed synthesis of fatty acid diethanolamides, J Agric. Food Chem, 2001, 49:5761-5764.

[12] L. Aloe, A. Leon, R. L. Montalcini. A proposed autacoid mechanism controlling mastocyte behavior, Inflm Res (1993) 39:145147.

[13] P. E. Fatarina dan B. Pramudono, Pembuatan Surfaktan Polyoxyethylene Dari Minyak Sawit: Pengaruh Rasio Mono-Digliserida Dan Polyethylen Glykol, Reaktor, 2009, Vol.12, No. 3, Hal. 175-182.

[14] R. Azarmi dan A. Ashjaran. Type and Application of some Common Surfactant, J. Chem. Pharm. Res., 2015, 7(2):632-640.

[15] R. M. Silverstein, et al. Spectrometric Identification of Organic Compounds, Seventh Edition, State University of New York, 2005.

[16] X. Wang, Z. Han, Y. Chen, Q. Jin, X. Wang, Scalable Synthesis Of Oleoyl Ethanolamide by Chemical Amidation In A Mixed Solvent, $J$ Am Oil Chem Soc, 2016, 93: 125-131.

[17] Z. Masyithah, Optimasi Sintesis Surfaktan Alkanolamida dari Asam Laurat dengan Dietanolamina dan N-Metil Glukamina Secara Enzimatik, Disertasi, Universitas Sumatera Utara, Medan, 2010. 